\title{
Rural Space as a Regional Resource for Education: \\ A Case Study of Education Farm Activities at Elementary Schools in Saga City
}

\author{
FUJINAGA Go \\ Faculty of Culture and Education, Saga University; Saga 840-8502, Japan. \\ E-mail:fujinago@cc.saga-u.ac.jp
}

Received September 24, 2009; Accepted December 12, 2009

\begin{abstract}
This research analyzes the spatial characteristics of rural Japanese communities under post-productivism, with particular emphasis on their educational functions. More specifically, it focuses on experience-based learning about agriculture, forestry and fishery industries. This type of learning is linked with dietary education, environmental education and aesthetic education, whose importance has been highlighted in recent years, in the context of education farm. The study takes two elementary schools in Saga City as examples, and examines the specific nature of their education farm activities, and their relationships with the local area. Most education farm activities in Japan are carried out at educational institutions such as schools. Therefore, in most cases such farm-related educational activities are conducted for local children, taking the school district as the basic unit. The materials and personnel used in these activities are of course mainly procured from within the local area. In other words, the instructional materials used by these programs are human resources primarily drawn from residents who have worked in the agriculture, forestry, and fishery industries, and the land resources which are the basis of their livelihood. In contemporary Japanese rural communities which are experiencing depopulation, aging, and declining educational capabilities, the use of the rural community space as a new regional resource that is different from economic consumption has great significance for developing new educational functions through educational institutions like schools.
\end{abstract}

Key words education farm, educational functions in rural communities, regional resources, rural space, Saga City

\section{Introduction}

The perception that rural communities are primarily places which produce and supply agricultural produce and other foodstuffs does not apply to modern rural communities. As the agriculture, forestry and fishery industries and thus the original functions of villages decline, attention is being drawn to other functional aspects of these communities, such as leisure and healing, historical and cultural value, and environmental conservation (Tabayashi and Fujinaga 2002). In fact, in modern Japan where urban lifestyle has penetrated even into rural areas, a kind of rural tourism has begun to spread, and a wide variety of facilities have appeared in many places, including farmers markets for fresh produce and marine products, farm guest houses, farm restaurants, and small community allotment gardens. Businesses which let people experience agriculture, forestry and fishery industries have stimulated interaction between cities and rural communities, and for some urban residents, rural life is becoming an expression of social status or identity. In short, modern rural communities are now characterized by providing new services in nonagricultural sectors.

The national government has called attention to the varied functions of agriculture and rural communities, in addition to their function of sustainably supplying food. These functions include the circulation of water (preventing flooding and soil erosion, and recharging groundwater), the elimination/alleviation of environmental loads (water and air purification), the preservation of biodiversity (preserving ecosystems and protecting wildlife), the conservation of land space (maintaining original scenery, creating artificial natural scenery, and providing green spaces), the creation and maintenance of local communities and culture (promoting local communities and preserving traditional culture), as well as the alleviation of urban stresses (health, recreation, relaxation, experience-based learning and education).

As part of a reassessment of rural communities which incorporates these various functions, Tachikawa (2005) 
believes that a phenomenon has arisen wherein demands are created on rural communities in areas beyond their base of agricultural production. The rural communities are then rebuilt in response to these demands, and consumption of these goods or services occurs. He describes this change as a shift from "productivism" to "post-productivism." He also observes that two types of "views" are being directed toward rural communities from the outside. One is the "consumer view" of tourism, shopping, recreation, experiences, and residency, and this is typified in descriptive terms such as "healing," "slow life," and "human revitalization." The other is the "political view" directed at rural communities as objects of politically-driven rejuvenation through exchanges and rural tourism between cities and rural communities, multi-functionality, and cultural landscapes. What these outside views directed at rural communities are looking for is rurality. In this regard, Cloke (1993) gives five elements of the rurality image consumed: landscape, history, family orientation, crafts and country fayre, and nature.

Of course, this reassessment of rural communities is also related to sustainable development and the preservation of modern rural communities now facing problems of depopulation, aging, and the lack of heirs. A key issue is how to position and utilize the various functions or potential functions of villages as part of a revitalization strategy for rural communities. ${ }^{1}$ Naturally, this involves more than action from the outside, and actions rural communities take toward village revitalization are also crucial for reorganization of rural space.

This study accepts the trend of post-productivism, and focuses on the educational functions of rural communities in order to analyze new spatial aspects of those communities. In recent years, attention has been drawn to the educational function, linked to "dietary/agriculture education" and "local production for local consumption," as one function of rural communities. Good examples of these educational functions are biological observation and farming experiences for elementary and junior high school students in satoyama areas (areas where mountains border on arable land).

On the other hand, such educational practices are not necessarily tied to the community area as the basis of livelihood. It is not denied that urban children occasionally go far from their town, and that they thus engage in biological observation and experience farming in a remote place. However, in the situation of today's rural villages which are facing the problem of survival of the community itself, as suggested by Iwasaki (2000), it can be important to have educational practices for local residents to learn about their local area but not as an objectified area or the outcome of environmental problems. Kanda (2006) follows this and concludes "that the practical approach of school education as composite learning rooted in the local community as the subject formation having its own field is evaluated as recovering the proper field newly rooted in the local communities, that villages are positioned as the means for it and that this view point is important in the analysis of dietary and agricultural education, village/self-rule public hall exercise and the community improvement that took root in the area." In other words, it may be said that taking the rural community space as a field for local community education in addition to its exploitation is important. We want to focus on a type of experience-based learning about agriculture, forestry and fishery industries called "education farm" to consider the practical educational activities in the area and the rural community space as its field.

\section{An Overview of Education Farm Activities in Japan}

There has been a lot of discussion in recent years about the importance of dietary education. The Dietary Education Law was enacted in 2005, and a Basic Plan for Promoting Dietary Education was formulated in 2006. In recent years, one approach to promoting dietary education has been a type of experience-based learning about the agriculture, forestry and fishery industries called "education farm." Education farm is defined as "an effort where people working in agriculture, forestry and fisheries provide opportunities to experience the processes of work in those areas, with the aim of deepening understanding of the various activities of people relating to the blessings of nature and food (April 12, 2006, Notice by the Director-General, Food Safety and Consumer Affairs Bureau, Ministry of Agriculture, Forestry and Fisheries)," and as efforts "where the same people perform at least two types of work on the same crop or product, for at least two days a year, under the guidance of people actually working in agriculture, forestry and fisheries (Study Group for Education Farm Promotion, Ministry of Agriculture, Forestry and Fisheries)." The Basic Plan for Promoting Dietary Education stipulated a goal of raising the percentage of municipalities with an organization acting independently to implement education farm from $42 \%$ to $60 \%$ over the 5 years from 2006 to 2010 . 
France is an example of a western country with an advanced education farm system. Oshima (1999) writes, "in school education in France, classes which visit farms are conducted to familiarize students with farms, as well as nature and environmental issues, and farms where these classes can be conducted are called 'education farms." She notes that students learn about food production while enjoying the visit to the farm itself, and those in higher grade levels can learn a variety of subjects in the context of an education farm-including French, math, social studies, science, art, music, physical education, and ethics-and this is likely to have educational effects with an impact in the local area. She also mentions the significance of education farms as a venue for interaction between cities and rural communities, through the farm's role in rural tourism, and the therapeutic effect of interaction with farming and livestock.

In Japan too, integration of education farm into the education system is now being considered due to heightened interest in dietary, aesthetic, and environmental education, and due to the aforementioned trends in western countries (Fujinaga 2009). In fact, many experiential projects in the agriculture, forestry and fishery industries were already being conducted within the Japanese education system even before the introduction of the new concept and hands-on activities of an "education farm."

Now, let us get an overview of education farm activities in Japan. In fiscal year 2006, the Ministry of Agriculture, Forestry and Fisheries conducted a nationwide "Factfinding Survey Regarding Efforts Toward Experiencebased Learning about Agriculture, Forestry and Fishery Industries (Education Farms)." The survey was designed to "summarize the results of fact-finding regarding efforts toward experience-based learning about agriculture, forestry and fishery industries (education farm), conducted in order to ascertain the actual situation in municipalities making efforts on education farm which provide opportunities for experience of agricultural work etc., with goals such as deepening understanding of the various activities of people relating to the blessings of nature and food." In particular, the Ministry sought to ascertain the situation in municipalities making efforts on education farm in accordance with the Basic Plan for Promoting Dietary Education formulated in March 2006 based on the Dietary Education Law. The survey was administered to 2,042 municipalities throughout Japan (as of February 6, 2006) and results were tabulated for the 2,040 municipalities which responded. ${ }^{3}$

Table 1 shows the situation for education farm efforts in municipalities. According to these figures, of 2,040 local governments nationwide, 1,172 municipalities (57.5\%) were implementing education farm or supporting education farm. Roughly $60 \%$ of local governments were engaged in education farm activities in some way.

Now let us look at the nature of these municipal education farm efforts. Figure 1 shows the number of municipalities for each type of effort. This table shows that education farm efforts involving educational institutions are by far the most common. ${ }^{4}$ Nationwide, 830 municipalities (70.8\%) are implementing or supporting education farm activities involving educational institutions. Education farm is not only for students and schoolchildren; it is for all citizens. However, the reason why local governments tend to adopt these activities is thought to be because educational institutions are facilities for ordinary education. The next most common effort is community gardening, which is being implemented or supported by 309 municipalities $(26.4 \%)$. This relates to the fact that in recent years community gardens have

Table 1. Education farm efforts of municipalities (2006)

\begin{tabular}{|c|c|c|c|c|c|}
\hline & Nationwide & $\begin{array}{l}\text { Municipalities } \\
\text { implementing themselves, } \\
\text { or supporting }\end{array}$ & $\begin{array}{l}\text { Implementing } \\
\text { themselves }^{2)}\end{array}$ & Supporting ${ }^{3)}$ & $\begin{array}{l}\text { Municipalities not } \\
\text { implementing or supporting }\end{array}$ \\
\hline Number of municipalities ${ }^{1)}$ & 2040 & 1172 & 582 & 872 & 868 \\
\hline Percentage (\%) & $(100.0)$ & $(57.5)$ & $(28.5)$ & $(42.7)$ & $(42.5)$ \\
\hline
\end{tabular}

1) Of the 2,042 municipalities throughout Japan as of Feb. 6, 2006, figures were tabulated for the 2,040 municipalities which responded.

2) In addition to efforts of the municipalities themselves, this also includes cases where education farm activities are implemented under the name of the municipality while relying on private contractors, and efforts by school boards. However, it excludes cases where activities are implemented independently by the elementary/junior high school etc. at its own discretion.

3) Activities other than education farm activities implemented by municipalities themselves include: (1) Cases where funds are provided for education farm efforts through means such as support programs provided by the municipality, (2) Cases where labor is provided instead of funds, such as providing information between involved persons, and PR both inside and outside of the municipality, and (3) Cases where activities are implemented by the third sector.

Source: The 2006 Ministry of Agriculture, Forestry and Fisheries fact-finding survey regarding efforts toward experience-based learning about agriculture, forestry and fishery industries (education farms). 


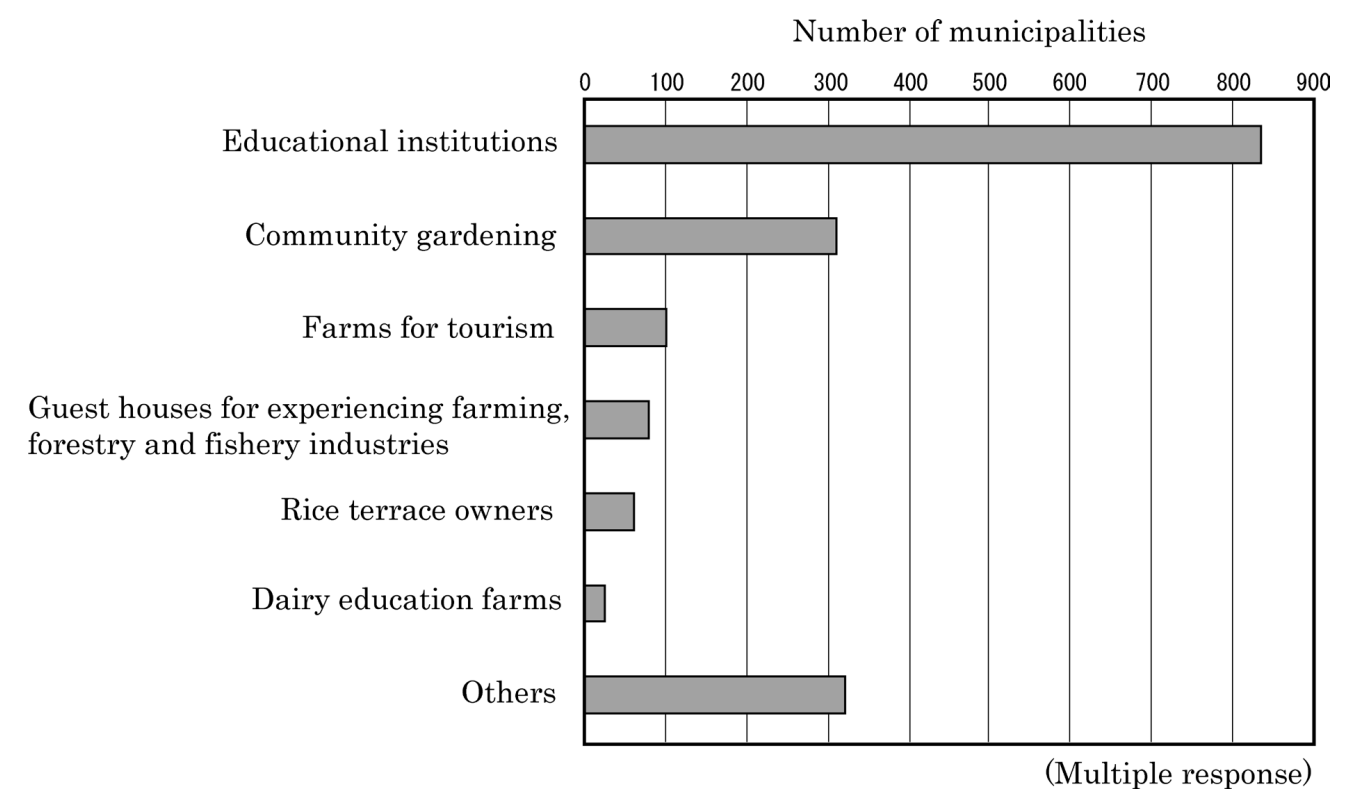

Figure 1. Number of municipalities either implementing themselves or supporting each type of education farm efforts (2006).

Of the 2,042 municipalities throughout Japan as of Feb. 6, 2006, figures were tabulated for the 2,040 municipalities which responded. Source: the 2006 Ministry of Agriculture, Forestry and Fisheries fact-finding survey regarding efforts toward experience-based learning about agriculture, forestry and fishery industries (education farms).

been created primarily for urban residents in city centers and in suburbs of large cities such as Tokyo and Osaka. Community gardens with lodging facilities, called allotment gardens, have also been established. Other efforts are also being made, although their percentages are low: farms for tourism (99 municipalities, 8.4\%), guest houses for experiencing farming, forestry and fishery industries (78 municipalities, 6.7\%), rice terrace owners (62 municipalities, 5.3\%), and dairy education farms (26 municipalities, $2.2 \%){ }^{5}$

Table 2 shows the number and percentage of municipalities where educational institutions are making efforts in education farm. The 1,426 municipalities accounts for $69.9 \%$ of the total, or roughly $70 \%$. This includes 830 of the aforementioned municipalities which are implementing education farm by themselves or providing support. In other words, of the municipalities where educational institutions are making education farm efforts, $58.2 \%$ are implementing the programs by themselves or providing support. In the remaining 596 municipalities (41.8\%) it is likely that elementary/junior high schools, day-care centers or other facilities are implementing education farm independently or at their own discretion.

As indicated above, education farm activities in Japan have a strong dependence on educational institutions, and there are many cases where public support is received from sources such as local government. Consequently, the

Table 2. Number of municipalities where educational institutions are making education farm efforts (2006)

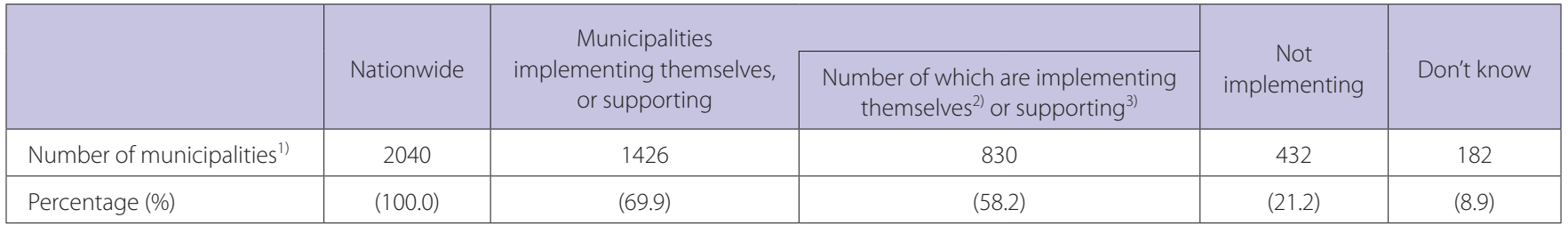

1) Of the 2,042 municipalities throughout Japan as of Feb. 6, 2006, figures were tabulated for the 2,040 municipalities which responded.

2) In addition to efforts of the municipalities themselves, this also includes cases where education farm activities are implemented under the name of the municipality while relying on private contractors, and efforts by school boards. However, it excludes cases where activities are implemented independently by the elementary/junior high school etc. at its own discretion.

3) Activities other than education farm activities implemented by municipalities themselves include: (1) Cases where funds are provided for education farm efforts through means such as support programs provided by the municipality, (2) Cases where labor is provided instead of funds, such as providing information between involved persons, and PR both inside and outside of the municipality, and (3) Cases where activities are implemented by the third sector.

Source: The 2006 Ministry of Agriculture, Forestry and Fisheries fact-finding survey regarding efforts toward experience-based learning about agriculture, forestry and fishery industries (education farms). 
system has been developed based on the "political view" of Tachikawa (2005), and activities are being conducted within that system. On the other hand, education farm implemented at educational institutions are frequently aimed at children in one region, not people from outside that area. The materials and personnel used in those activities are primarily procured from within the region. The activities are limited to the institutional framework of the school district, but rural communities have a certain degree of social relationships which transcend administrative divisions, and activities are conducted within that wider geographical scope.

The following section discusses educational functions of rural communities, while taking into account the aforementioned distinguishing features of education farm in Japan by case studies of elementary schools in Saga City. Saga Prefecture, which includes Saga City, is currently working actively on an education farm project. According to the "Fact-finding Survey Regarding Efforts Toward Experience-based Learning about Agriculture, Forestry and Fishery Industries (Education farm)," 26 of 29 local governments in Saga Prefecture in 2006 (93.1\%) supported education farm activities in one way or another (the third most in the whole country). In addition, educational institutions carry out education farm activities in 25 local governments. Most of the content of this education farm is developed in blocks of school districts in local areas, and it may be said that it is an appropriate example field in this study.

\section{Cases of Education Farm Activities at Elementary Schools in Saga City}

The examples discussed here are Matsu-ume Elementary School and Kase Elementary School (Figure 2 ). For the education farm at each elementary school,

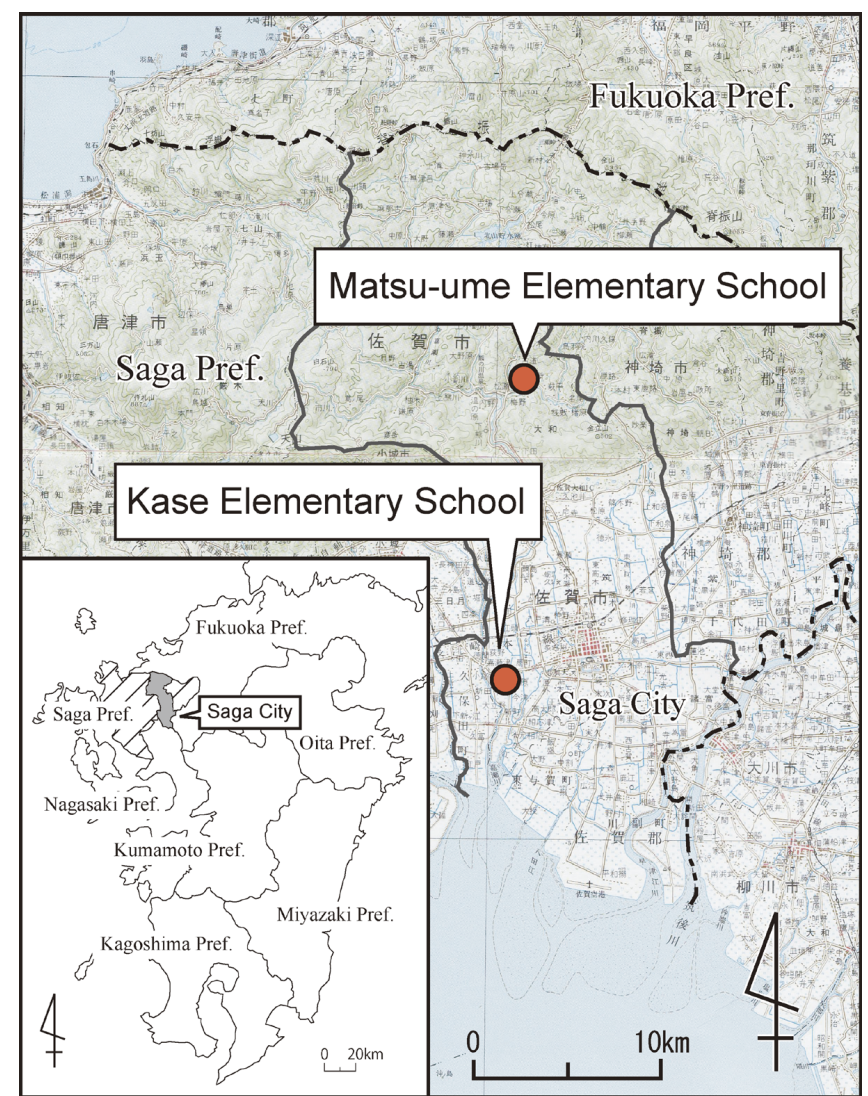

Figure 2. Location of example elementary schools.

we shall examine the specific activity content, activity locations, supporters/groups and other factors.

\section{The case of Matsu-ume Elementary School}

Matsu-ume Elementary School is located in the former municipality of Yamato-cho north of Saga City, in the southern foothills of the Sefuri Mountains. It is located only 20 minutes by car from the Saga City center where the prefectural office is located. Many residents work at non-agricultural jobs while remaining engaged in agriculture.

Table 3 provides a description of the main education

Table 3. Description of education farm activities at Matsu-ume Elementary School (2007)

\begin{tabular}{|c|c|c|c|c|c|c|}
\hline Description of activity & $\begin{array}{l}\text { Participating } \\
\text { grades }\end{array}$ & Activity location & Times/year & Year started & Supporting groups & Remarks \\
\hline $\begin{array}{l}\text { Rice planting/ } \\
\text { harvesting }\end{array}$ & 5,6 & School rice paddy & 2 & - & Farmers, JA & $\begin{array}{l}\text { Make mochi (rice } \\
\text { cakes) with harvested } \\
\text { rice }\end{array}$ \\
\hline Vegetable cultivation & All grades & $\begin{array}{l}\text { School vegetable } \\
\text { garden }\end{array}$ & $10-30$ & - & Farmers & \\
\hline Potato cultivation & All grades & $\begin{array}{l}\text { School vegetable } \\
\text { garden }\end{array}$ & 4 & - & Farmers & $\begin{array}{l}\text { Use some harvested } \\
\text { potatoes in school } \\
\text { meals }\end{array}$ \\
\hline $\begin{array}{l}\text { Making dried } \\
\text { persimmons }\end{array}$ & All grades & School & 5 & 1999 & $\begin{array}{l}\text { Farmers, Senior } \\
\text { citizens association, } \\
\text { PTA }\end{array}$ & \\
\hline
\end{tabular}

Source: Interview survey. 


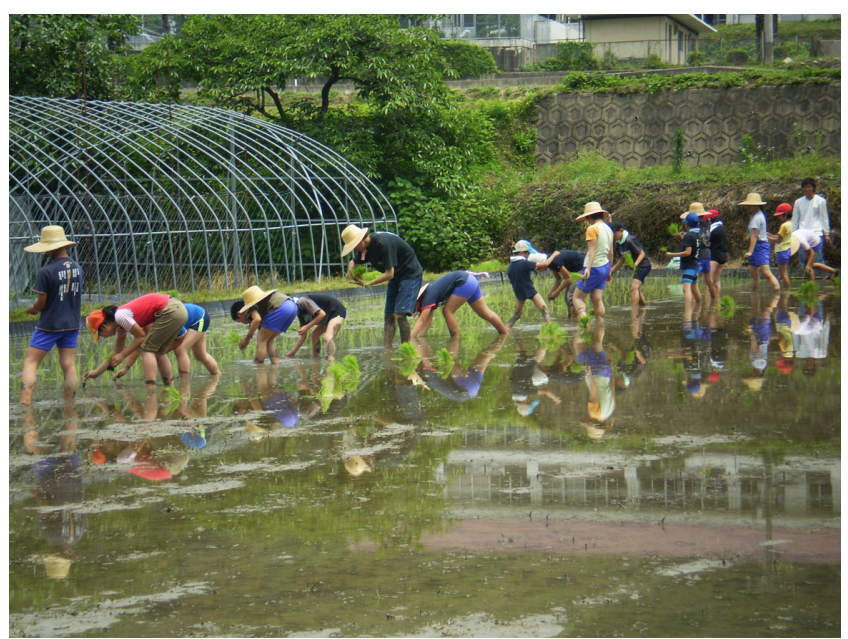

Figure 3. Rice planting at school rice paddy (Jun. 2008).

Courtesy of Matsu-ume Elementary School.

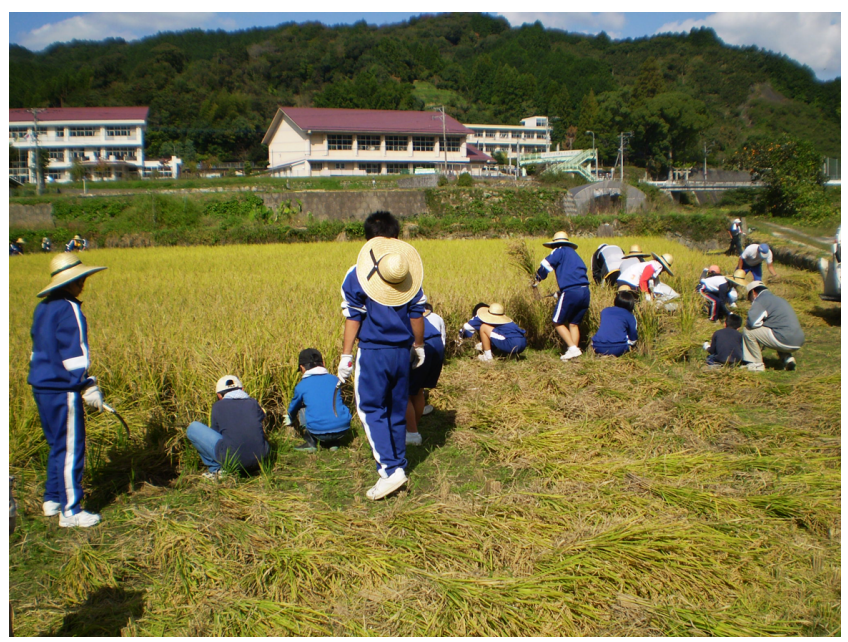

Figure 4. Rice harvesting at school rice paddy (Dec. 2008).

Courtesy of Matsu-ume Elementary School.

farm activities at Matsu-ume Elementary School. The school provides experience-based learning on agriculture, such as rice growing and vegetable cultivation.

Two main types of experience-based learning are provided for rice growing: rice planting and rice harvesting (Figures 3,4 ). The activity location is a roughly $200 \mathrm{~m}^{2}$ school rice paddy, rented from a farmer in the school district, and located about a 5 minute walk from the school. The school relies on neighboring farmers in the school district to provide instruction in agricultural techniques and to provide materials such as farm implements. Students also learn about the history of agriculture in the region by experiencing agricultural work with equipment like winnowers and comb threshers (Figures 5, 6).

For vegetable cultivation, the school also rents $100 \mathrm{~m}^{2}$ of land each for the elementary school and junior

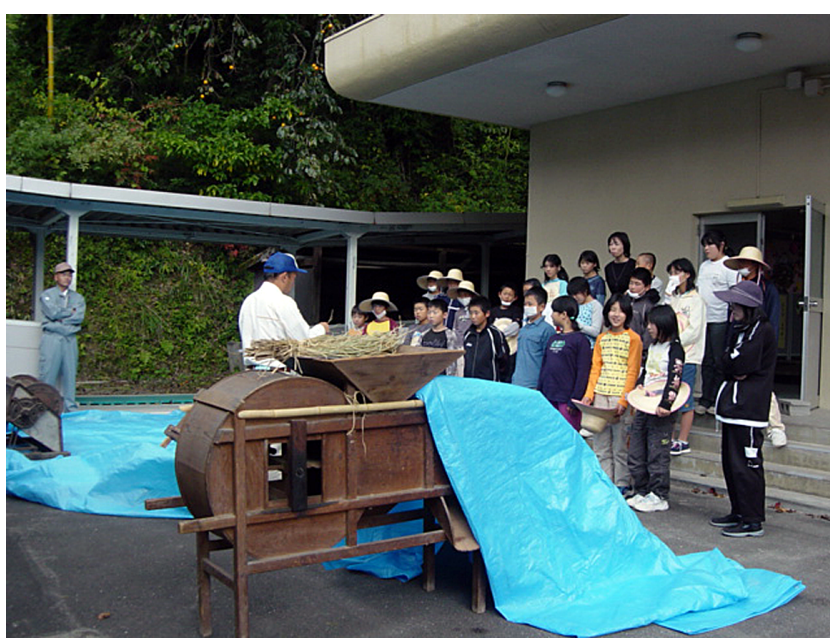

Figure 5. Experiencing winnowing using a winnower (Sept. 2006).

Courtesy of Matsu-ume Elementary School.

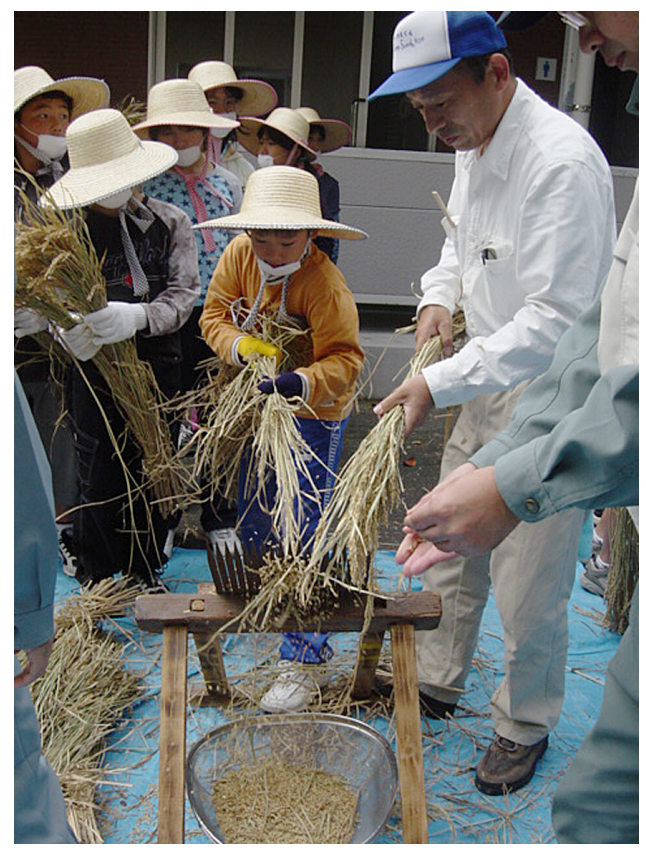

Figure 6. Experiencing threshing using a comb thresher (Sept. 2006).

Courtesy of Matsu-ume Elementary School.

high school from a temple located immediately to the west of the elementary school, and uses those plots as school vegetable gardens. Originally, this temple was also engaged in agriculture as a sideline, but after the household head passed away, the family scaled back to cultivating vegetables to supply their own needs, and rented out the excess cropland to the school. In the school gardens, students cultivate vegetables and fruits throughout the year, including cucumbers, eggplants, tomatoes, green peppers, okra, watermelon, and melons (Figure 7). The school relies on former teachers at the school and members of the agricultural cooperative, 


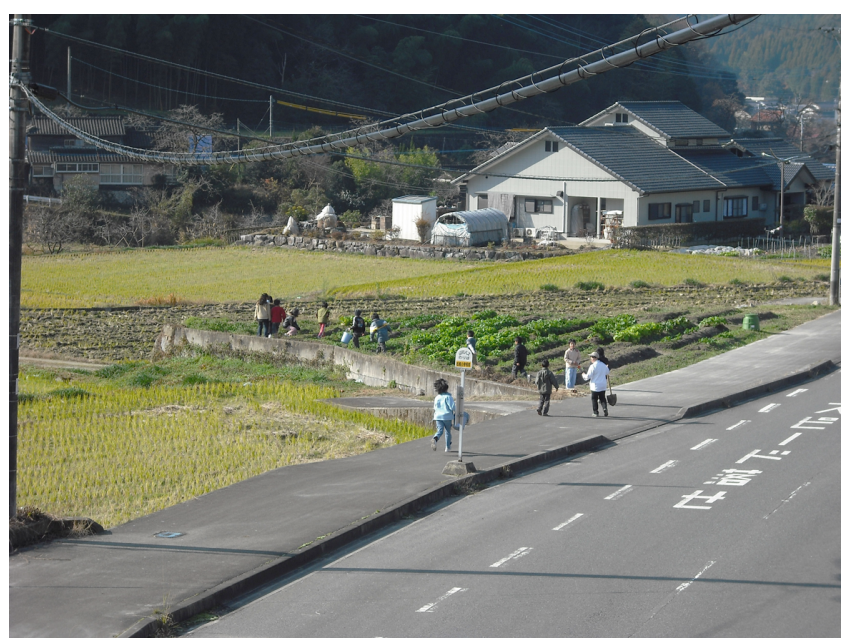

Figure 7. School vegetable garden and children (Dec. 2008).

Courtesy of Matsu-ume Elementary School.

who are full-time and part-time farmers in the nearby area, to provide guidance on tasks such as mulching and fruit picking, and to provide materials such as fertilizer. As part of dietary education, the schoolchildren prepare some of the harvested vegetables, and some are also used in school meals.

Prior to the 2007 school year, Matsu-ume Elementary School utilized support from the Ministry of Education, Culture, Sports, Science and Technology (MEXT) in conducting vegetable cultivation. The MEXT "Project for Promoting Rich Experiences" was launched in 2002 to promote "various activities to experience nature, social service, and human interaction" at schools with "the aim of making young students more social, and more enriched as human beings." In response, elementary and junior high schools throughout Japan have been conducting activities such as providing students with agricultural experiences. Since the 2008 school year, Matsu-ume Elementary School has also been growing vegetables with the support of Saga Prefecture's "Only One Saga Project for Supporting Experience Activities." This is an education support project of Saga Prefecture which was launched in fiscal year 2004, with the goal of promoting experiential activities not only in the agriculture, forestry, fishery and traditional industries which are characteristic of Saga Prefecture, but also (since fiscal year 2007) in tourism, commerce, and modern industries. ${ }^{6}$ The experience-based learning about vegetable cultivation has thus been implemented at Matsu-ume Elementary School with political support from the national and prefectural government.

The school has also created a potato field on school grounds where they are cultivating sweet potatoes.

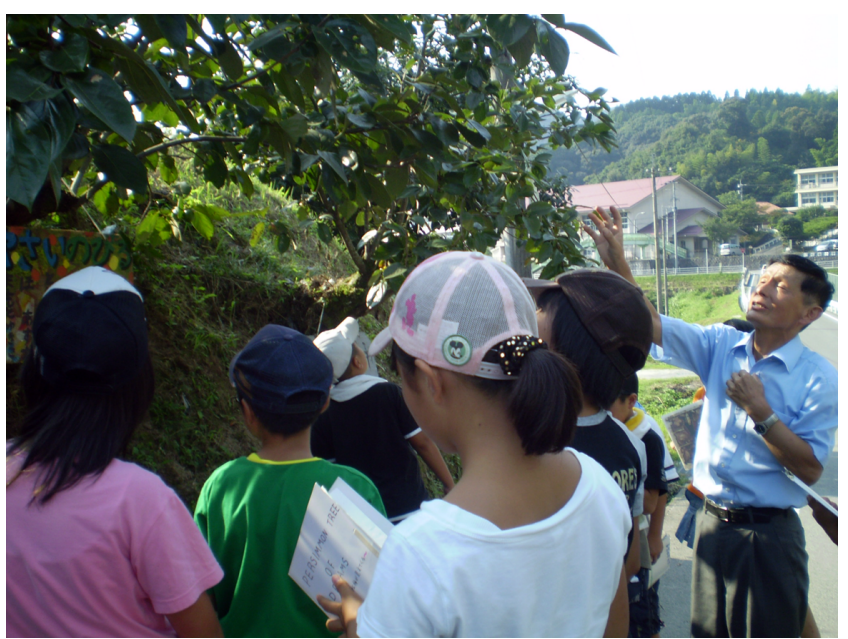

Figure 8. Instruction by local persimmon grower (Aug. 2008).

Courtesy of Matsu-ume Elementary School.

Kindergartners also participate in this cultivation. The former Yamato-cho, where Matsu-ume Elementary School is located, was originally a dried persimmons producing area, and making dried persimmons is part of the experience-based learning. Naturally, students cannot experience the entire process of persimmon cultivation from beginning to end, but the school works with local persimmon growers, and students learn about persimmon cultivation in actual orchards. A few persimmon trees near the school are also rented so that students can observe how persimmons grow (Figure 8). Dried persimmons are made at the elementary school, with the assistance of parents and nearby farmers. Most parents are part-time farmers, and almost all parents, including new residents, help in making dried persimmons. Dried persimmons are made in November every year, but tasks such as securing persimmons to process, building a drying shed, and procuring other materials are done with the support of parents and other local residents (Figure 9). The persimmons are stored in a refrigerator, and this refrigerator too is provided by local persimmon growers. In the actual process of making of dried persimmons, local farmers provide instruction on work such as peeling the skin. Most of these farmers are grandparents of students or previous graduates who used to be engaged in making dried persimmons, and this program allows them to put their experience to use (Figure 10). Persimmon peeling is not only done by the children. Residents and foreign students from the local area and neighboring municipalities also take part, and this is a large and popular event.

The roadside station "Soyokaze Kan" is located in the school district of Matsu-ume Elementary School. The 


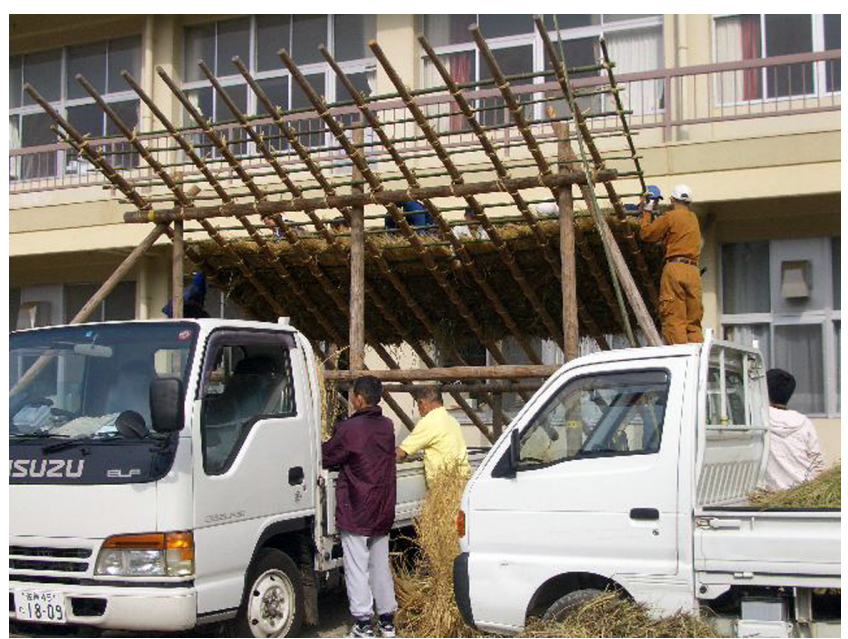

Figure 9. Parents and local farmers helping to build a shed for persimmon drying (Nov. 2008).

Courtesy of Matsu-ume Elementary School.

station has a farmer's market where local farmers sell their rice and vegetables to consumers, and in some years the students get to experience selling vegetables and dried persimmons.

\section{The case of Kase Elementary School}

Matsu-ume Elementary School has accepted national and prefectural support for the deployment of an education farm project, but on the other hand, though there are few examples, some elementary schools have created networks with local residents in the district and are doing original education farm activities. One example is Kase Elementary School in Saga City, which is introduced here. Kase Elementary School is located in the western suburbs of Saga City, in the center of the Saga Plain, which is famous for its creeks. Many of the local residents are part-time farmers.

Table 4 gives an overview of education farm activities at Kase Elementary School. As at Matsu-ume Elementary

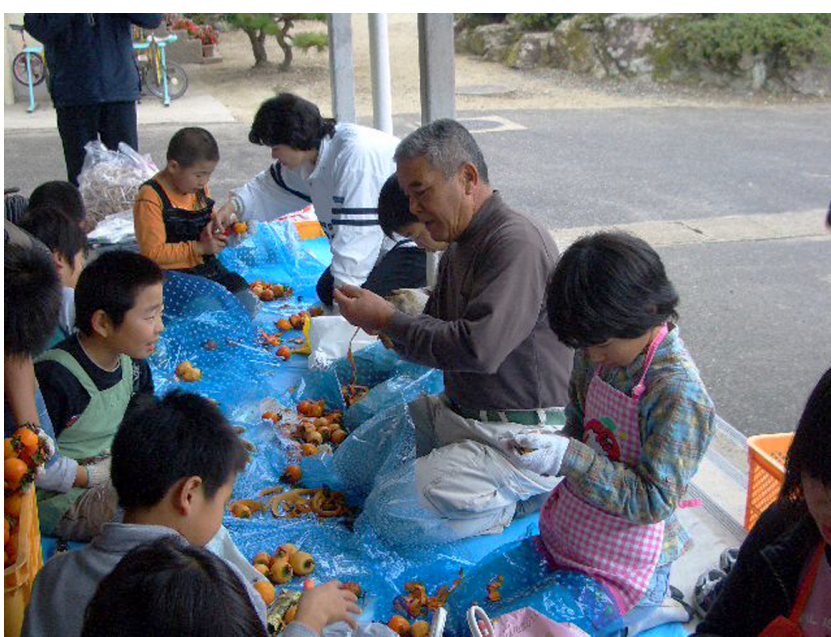

Figure 10. Practice and instruction on persimmon peeling by parents and local farmers (Nov. 2008).

Courtesy of Matsu-ume Elementary School.

School, the focus of experience-based learning about agriculture at Kase Elementary School is rice growing and vegetable cultivation. Rice growing is done at an approximately $1000 \mathrm{~m}^{2}$ training paddy located about 5 minutes walk from the school. This training paddy is rented from an individual farmer in the local area. Instruction is provided by the youth group of the agricultural cooperative. Nevertheless, most instructors are parents, and are engaged in agriculture (Figure 11).

A garden has been created on school grounds for vegetable cultivation, and a variety of produce is grown, including cucumbers, broccoli, asparagus, potatoes, Chinese cabbage, Japanese radish, and strawberries. Local farmers and the senior citizens association provide guidance on techniques such as seed sowing, seedling transplantation, and harvesting, and they also provide seeds, fertilizer, and other agricultural materials (Figure 12). A greenhouse is used for cucumber cultivation and

Table 4. Description of education farm activities at Kase Elementary School (2007)

\begin{tabular}{|c|c|c|c|c|c|c|}
\hline Description of activity & $\begin{array}{l}\text { Participating } \\
\text { grades }\end{array}$ & Activity location & Times/year & Year started & Supporting groups & Remarks \\
\hline Vegetable cultivation & 2 & $\begin{array}{l}\text { School vegetable } \\
\text { garden }\end{array}$ & 5 & 2004 & $\begin{array}{l}\text { Senior citizens } \\
\text { association }\end{array}$ & $\begin{array}{l}\text { Use some harvested } \\
\text { vegetables in school } \\
\text { meals }\end{array}$ \\
\hline $\begin{array}{l}\text { Rice planting/ } \\
\text { harvesting }\end{array}$ & 5 & $\begin{array}{l}\text { Rice paddy of } \\
\text { private individual }\end{array}$ & 3 & 2003 & Private individual, JA & $\begin{array}{l}\text { Experience making } \\
\text { mochi (rice cakes) with } \\
\text { harvested rice }\end{array}$ \\
\hline $\begin{array}{l}\text { Cucumber cultivation/ } \\
\text { sale }\end{array}$ & 5 & $\begin{array}{l}\text { School vegetable } \\
\text { garden }\end{array}$ & 20 & 2004 & Farmers & $\begin{array}{l}\text { Use some harvested } \\
\text { cucumbers in school } \\
\text { meals }\end{array}$ \\
\hline $\begin{array}{l}\text { Nori (dried seaweed) } \\
\text { making }\end{array}$ & 5 & Nori making area & 1 & 2005 & $\begin{array}{l}\text { Ariake Sea Fishing } \\
\text { Coop }\end{array}$ & \\
\hline
\end{tabular}

Source: Interview survey. 


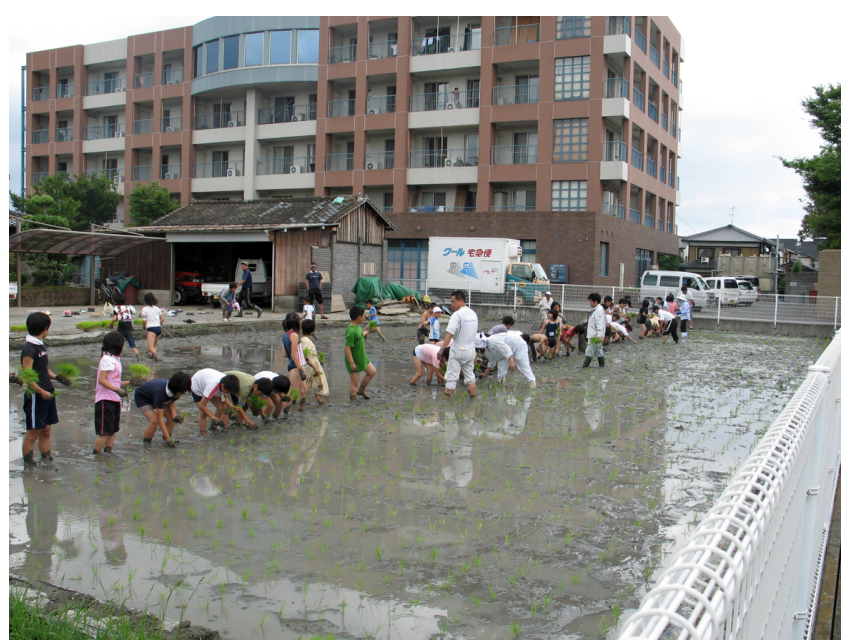

Figure 11. Instruction on rice planting by youth group of agricultural cooperative (Jun. 2007).

Courtesy of Kase Elementary School.

the installation and materials for this greenhouse were provided by a local farmer.

The vegetables cultivated and harvested by the children are used in school meals or sold at the local culture festival held in early December. The school, the local government, the senior citizens association and the producer cooperative organize an executive committee for this local culture festival, and the festival is held in the community center. At that time, the parents, as well as parents and grandparents of previous graduates, work together with farmers and the senior citizens association to help the children sell vegetables (Figure 13).

In this way, Kase Elementary School conducts education farm activities with the assistance of parents, farmers and the agricultural cooperative, just like Matsuume Elementary School. However, unlike Matsu-ume Elementary School, Kase Elementary School does not receive national or prefectural support from sources such as the "Rich Experience Project" or the "Only One Project."

\section{Education Farm and Educational Functions of Rural Space}

The sections above have introduced education farm activities using two elementary schools in Saga City as examples. Both schools have been actively making efforts in experience-based learning about agriculture through activities such as rice growing and vegetable cultivation. Matsu-ume Elementary School is conducting education farm activities while receiving political support from the national and prefectural government through the "Project for Promoting Rich Experiences" and the "Only One

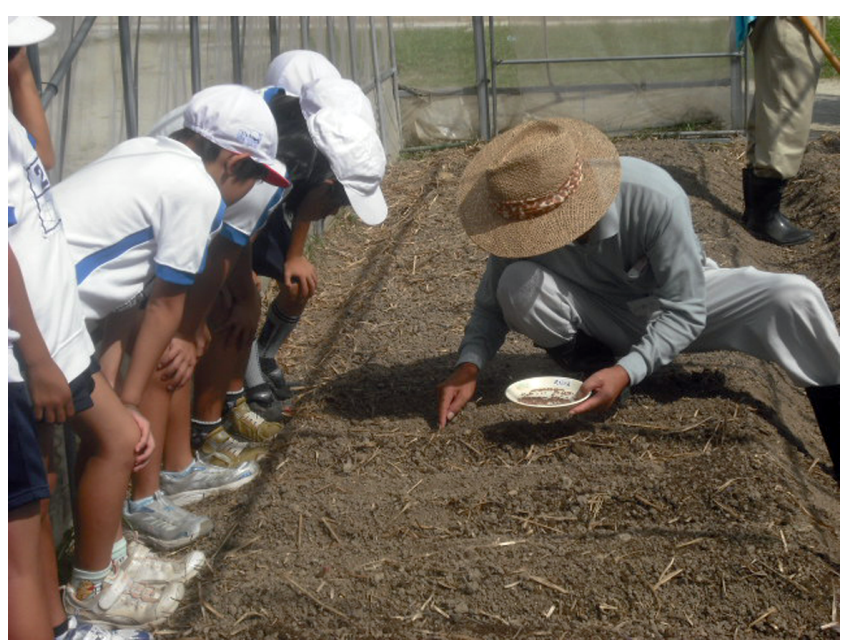

Figure 12. Instruction on seed sowing by local farmer (Aug. 2008).

Courtesy of Kase Elementary School.

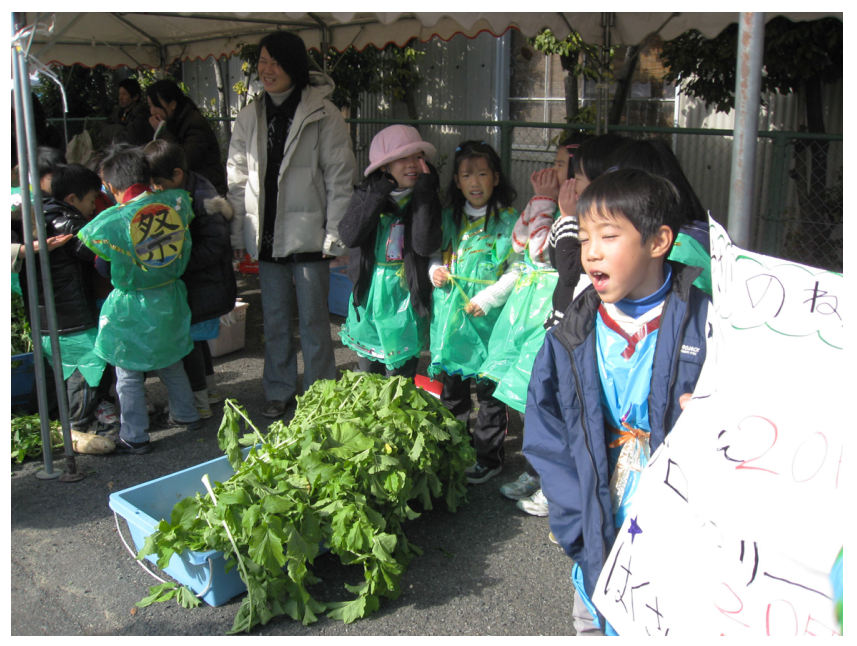

Figure 13. Experiencing vegetable sales at local culture festival (Dec. 2008).

Courtesy of Kase Elementary School.

Saga Project for Supporting Experience Activities." Kase Elementary School, on the other hand, has incorporated education farm activities into its school education program on its own initiative. The two differ in whether they are receiving political support, but they are similar in that they both use resources such as people and land which are available in the local area.

Figure 14 shows the distribution of local residents and activity locations involved in the education farm of Matsu-ume Elementary School. This map shows that people, organizations, facilities, and farm land are linked together around the nucleus of the school. The education farm program makes use of the human infrastructure of local farmers, their wisdom and agricultural techniques, and the land infrastructure of farm land and forests which the farmers use as the basis of their productive 


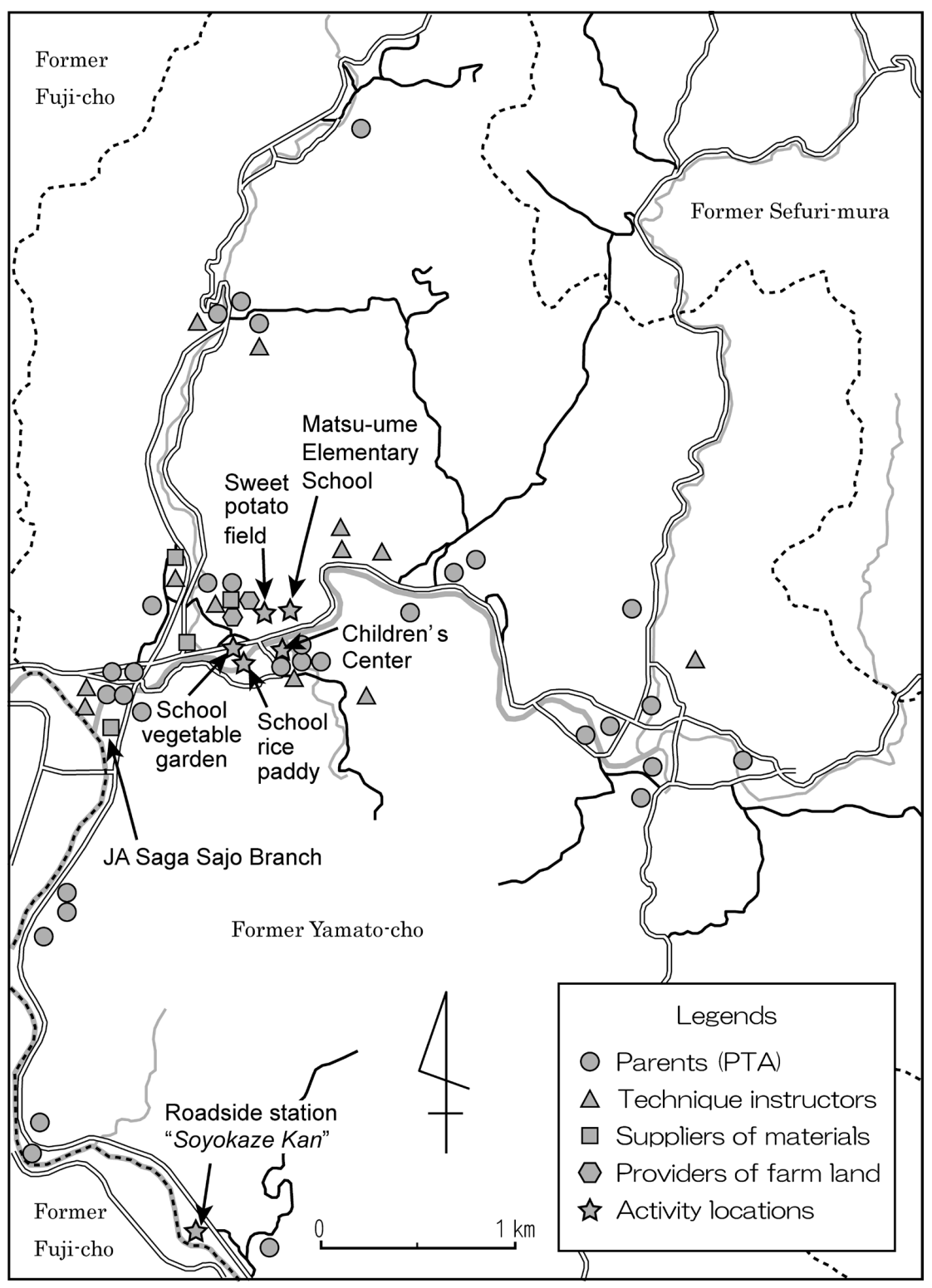

Figure 14. Distribution of activity locations and involved persons for the education farm program of Matsu-ume Elementary School (2009).

Source: Field survey.

activities. This also includes idle fields and abandoned cropland. Furthermore, many farmers are parents or grandparents of current students or graduates, and the school's environment is such that it is easy to enlist local residents' help in school education. The school has formed an organization incorporating the ParentTeacher Association (PTA), the producer cooperative, the women's association, and the senior citizens association, and members help with education farm activities not as individuals but as social groups. The school district has facilities like the roadside station, which has an agricultural cooperative and farmer's market, and an education farm support system which provides materials and locations. This approach is distinctive in that the potential human and land resources originally existing in the area are used as instructional materials for the local children, not consumed with economic compensation through farm work experiences or craft-making experiences aimed at tourists. Kase elementary school is similar. In other words, instead of a local community weakened by depopulation, aging, and shifting to parttime work and penetration of urban lifestyles, here we catch a glimpse of education farm as a means of passing down the lifestyles, culture, folkways and history of the local area. Through education farm activities centered on schools, local residents in rural communities form new local connections to support those activities, and pass down the traditions of the local area. Here, there is an educational function of rural communities which is separate from economic consumption. 
In terms of the reproduction of constituent members of society, the educational function of a rural community was originally something possessed by the region itself, and the institution of modern school education itself is a policy of the national government. ${ }^{7}$ There is also an overlap with the school district established as the spatial range of the local area in this case. However, under the present conditions where these educational capabilities of rural communities are weakening, the rural community space-incorporating the people and land that built up an enduring way of life and culture when the education setting was the local area itself or was linked with the local community-exhibits new education functions through the educational institution of schools. ${ }^{8}$

\section{Conclusion}

This study has discussed the education functions of the rural community space, illustrated by education farm activities at elementary schools in Saga City. Japanese rural communities under post-productivism are entering a new period of transition, with the "view" of outsiders looking in and an internal response to those pressures. Urban residents are looking for rurality as an object of consumption, and rural communities are responding by developing "products" and "services" to meet that demand. Under these circumstances, rural communities must aim to establish their own identity while simultaneously selling their own culture (Fujinaga 2006). Cloke and Thrift (1987) and Thrift (1987) point out that powerful people in corporations or state institutions, i.e., the urban residents who are the agents of consumption, tend to change rural space to suit their own tastes. ${ }^{9}$ There lies a dilemma for rural communities in Japan. These considerations show why it is critical to use and evaluate rural space as regional resources in education activities, not just as objects of economic consumption.

The education farm activities discussed here will not always contribute to the reproduction of local society. The process will be mediated by the fluid political institution of education and educational institutions such as schools. Temporarily, it may do nothing more than supplement part of the role of village society as transmitter of tradition. However, more than anything, when we notice the wisdom, techniques and experience which local society has accumulated in its long history, it is at least conceivable, even within the externally-imposed framework of government policy, that "self-directed" use of rural space as a regional resource for education farm activities has potential as a type of autonomous community movement, though small, helping to break away from the national standard of productivism.

\section{Acknowledgements}

The author would like to thank everyone at Matsuume Elementary School and Kase Elementary School for their help during my field investigation. This research was partially supported by a Grant-in-Aid for scientific research (A) 2008and 2009, "Human Geographical Study on Rural Space as Commodity" (Representative: Akira Tabayashi, Proposal Number 19202027). The author would like to thank Professor Akira Tabayashi (University of Tsukuba) and Professor Toshio Kikuchi (Tokyo Metropolitan University) and the other professors of the research group for their detailed and helpful advice.

An outline of this research was presented at the Study Meeting of the Association of Japanese Geographers, Spring 2008 (at Teikyo University).

\section{Notes}

1. See ed. by the Japanese Association for Rural Studies (2008).

2. This group was established as an advisory body for the Director-General, Food Safety and Consumer Affairs Bureau, Ministry of Agriculture, Forestry and Fisheries to examine policy and other actions necessary for promoting education farm activities. Specific examples of education farm activities at educational institutions throughout Japan are shown in "GO! GO! Education Farms: Case Studies" published in 2007 by the Consumer Information Officer of the Food Safety and Consumer Affairs Bureau, Ministry of Agriculture, Forestry and Fisheries.

3. A similar nationwide survey was conducted in fiscal year 2007, but it was decided to address the survey results for fiscal year 2006 in this report because of the reduction in the number of local governments due to the so-called "great Heisei merger" and changes in the survey items.

4. Here the term "educational institutions" refers to both private and public elementary/junior high schools and day-care centers, and excludes activities where cultivation is done using pots, planters or other containers.

5. The term "dairy education farm" refers to a "ranch having functions and an environment suitable as a venue for education," as defined by the Dairy Education Farm Promotion Committee established by the Japan Dairy Council in 1998 .

6. In 2007, 172 schools in Saga Prefecture were involved in the Only One Project, and of those, 134 schools were conducting experience activities relating to agriculture, forestry and fishery industries.

7. For a discussion of local areas, education and policies relating to rural communities, see ed. by Japanese Association for Rural Studies (2006). 
8. See, for example, Ohe (2004).

9. On the other hand, Phillips (1998) asserts that the middle class is not the only agent shaping rural space, and that other factors such as race and age act on the organization of rural space. Details on this are given in Takahashi (1999)

\section{References}

Cloke, P. 1993. The countryside as commodity: New rural spaces for leisure. In Leisure and the environment: Essays in honour of Professor J. A. Patmore, ed. S. Glyptis, 53-67. London: Belhaven Press.

Cloke, P. and Thrift, N. 1987. Intra-class conflict in rural areas. Journal of Rural Studies 3: 321-334.

Fujinaga, G. 2006. Mura no fuukei ga katarumono: Sekaiisan Shirakawa-gou wo tazunete (The story told by landscape of village: Visiting the world heritage site of Shirakawa-go). Study of Nonwritten Cultural Materials 11: 18-19. (J)

Fujinaga, G. 2009. Wagakuni ni okeru kyouiku-faamu no jissen joukyou to chiikitekisai (Regional differences on activities of education farms in Japan). Journal of Studies on Educational Practices, Saga University 25:107-116. (J)

Iwasaki, M. 2000. The meaning of the process of modernization at Anjo region: Change and revival of the "field". In The twentieth century system in Japanese rural societies: Beyond production absolution, ed. Japanese Association for Rural Studies, 85-116. Tokyo: Rural Culture Association. (JE)

Japanese Association for Rural Studies 2006. Education embedded in community and agriculture. Tokyo: Rural Culture Association. (JE)
Japanese Association for Rural Studies 2008. New developments of green tourism in rural Japan: Urban-rural exchanges as a strategy to revitalize farming areas. Tokyo: Rural Culture Association. (JE)

Kanda, Y. 2006. Education in the local community and rural, agriculture, peasant. In Education embedded in community and agriculture, ed. Japanese Association for Rural Studies, 7-41. Tokyo: Rural Culture Association. (JE)

Ohe, Y. 2004. Educational function as multifunctionality in agriculture: A case of dairy farms providing farming experience study. Technical Bulletin of Faculty of Horticulture, Chiba University 58: 17-27. (JE)

Oshima, J. 1999. Furansu no kyouiku-faamu. (Education farm of France). Tokyo: Japan Educational Press. (J)

Phillips, M. 1998. The restructuring of social imaginations in rural geography. Journal of Rural Studies 14: 121-153.

Tabayashi, A. and Fujinaga, G. 2002. Characteristics of agriculture in the Hokuriku district. Tsukuba Studies in Human Geography 26: 1-23. (JE)

Tachikawa, M. 2005. Post-productivist transition of rural Japan and transformation of its social representation. Annual Bulletin of Rural Studies 41: 7-40. (JE)

Takahashi, M. 1999. Post-productivist countryside, commodification and rural planning: Notes on social construction of ruralityII. Studies in Informatics and Sciences 9: 79-97. (JE)

Thrift, N. 1987. Manufacturing rural geography? Journal of Rural Studies 3: 77-81.

(J): written in Japanese

(JE): written in Japanese with English abstract 